\title{
Improving Speaking Skill by Using Group Work Method
}

\author{
Merla \\ Politeknik ATI Makassar \\ merla@atim.ac.id
}

\begin{abstract}
There are four skills in English and one of the skills that students think is very difficult is speaking. Speaking is the skill that needs more practice and exercise, otherwise speaking fluency cannot be improved. Teacher needs to use different teaching techniques in order to reach all students effectively. The objective of this research is to see whether the method in teaching Speaking English by using the group work technique has a positive effect on the academic achievement of the students at Polytechnic ATIM (ATI Makassar), especially for Agro Industrial Engineering students who studied at the second grade. This research was carried out through class action research where teacher give some materials, apply the method, then give direct testing such as written test to find out how far students understand about the materials after they discussed in group. It is one of the assessment materials. Others assessments are taken from groups' activities in class room, groups' presentation, Individual's interview test and questionnaire. This technique plays a positive role in improving the academic achievement in speaking. The technique can also improve students' motivation in learning English; develop their Self-confidence and cooperation among students. The finding from questionnaire proves that this method can also be used to improve students' mastery of grammar in use and motivate students in learning grammar. The method promotes learner autonomy by allowing students to make their own decision in the group without being told what to do by the teacher.
\end{abstract}

Keywords: group work technique, motivation, self-confidence, speaking

\section{INTISARI}

Ada empat keterampilan dalam bahasa Inggris dan salah satu keterampilan yang menurut siswa sangat sulit adalah berbicara. Berbicara adalah keterampilan yang membutuhkan lebih banyak praktik dan latihan; jika tidak maka keterampilan tidak dapat ditingkatkan. Guru perlu menggunakan teknik pengajaran yang berbeda untuk menjangkau semua siswa secara efektif. Tujuan dari penelitian ini adalah untuk melihat apakah metode pengajaran Speaking English dengan menggunakan teknik kerja kelompok memiliki efek positif terhadap prestasi akademik siswa di Politeknik ATIM (ATI Makassar), khususnya untuk mahasiswa Teknik Industri Agro yang belajar di kelas dua. Penelitian ini dilakukan melalui penelitian tindakan kelas di mana guru memberikan beberapa materi, menerapkan metode, kemudian memberikan pengujian langsung seperti tes tertulis untuk mengetahui sejauh mana siswa memahami tentang materi setelah mereka diskusikan dalam kelompok. Ini adalah salah satu bahan penilaian. Penilaian lain diambil dari kegiatan kelompok di ruang kelas, presentasi kelompok, tes wawancara individu dan kuesioner. Teknik ini memainkan peran positif dalam meningkatkan prestasi akademik dalam berbicara. Teknik ini juga dapat meningkatkan motivasi siswa dalam belajar bahasa Inggris, mengembangkan kepercayaan diri dan kerjasama di antara para siswa. Temuan dari kuesioner membuktikan bahwa metode ini juga dapat digunakan untuk meningkatkan penguasaan tata bahasa siswa dalam penggunaan dan memotivasi siswa dalam belajar tata bahasa. Metode ini mempromosikan otonomi pelajar dengan memungkinkan siswa untuk membuat keputusan sendiri dalam kelompok tanpa diberi tahu 
apa yang harus dilakukan oleh guru.

Kata kunci: berbicara, motivasi, percaya diri, teknik kerja kelompok

\section{INTRODUCTION}

The global development in the 21 st century is largely marked by the extensive use of a particular language that is English as lingua franca amongst most people across the globe. English may not be the most spoken language in the world, but it is the official language of 53 countries and spoken by around 400 million people across the globe. It is the most common second language in the world. Since English is widely spoken in the world, the teaching of English in Indonesia is developing rapidly day by day. It is cited by national choice at the beginning of independence in 1945 and reconfirmed by the decree of minister of education No. 096/1967, 12 December 1967. (Zainal: 2009). It was also supported with the Curriculum 1984 and 1994 which aspired to build students' ability to communicate in English actively (Lie: 2008). English is then assumed as being an important subject that must be taught at schools. There are four skills in English and one of the skills that students think is very difficult is speaking. We cannot deny that Speaking as the skill that needs much exercise and practice, otherwise speaking skills cannot be improved. Brown (1994: 225) has stated that "one of the obstacles in learning speaking is the anxiety generated over the risks of blurting things out that are wrong, stupid or incomprehensible". The feeling of afraid and shy to make mistake in speaking is the most popular reason why some students do not want to speak.

Based on my experience during many years teaching, I identified many problems in teaching of speaking to the first year students at Polytechnic ATI Makassar. First, the students have many difficulties in performing speaking that ruin most of the students' confidence to use English in their speaking class. Second, the students have low motivation to improve their speaking skills because they said that teachers seldom give them much time to speak. Third, the class is dominated by teachers' speech not students', as the teachers serve as the center of learning. Fourth, the students have poor mastery of vocabulary and grammar to utilize in discussion because teachers' material are not interesting for them. Therefore a good teacher should choose a method that can answer the identified problems above.

It cannot be denied that teaching English is not as simple and as easy as it seems. Teacher needs to use different teaching techniques in order to reach all students effectively. A variety of teaching strategies, a knowledge of student levels, and an implementation of which strategies are best for particular students can help teachers to know which teaching methods will be most effective for the students (Harris: 2003). Some teachers are still confused to decide the way to teach speaking effectively. There are many factors which contribute to why one technique or method that teacher used was unsuccessful to cope with such as the learners' differences, learners' motivation, teachers' role, etc. Those aspects should be considered before deciding the method that will be used.

There are many techniques that can be applied and one of them is group work. The researcher chose this technique after considering the factors that can hinder the implementation of successful technique such as learners' motivation, different social background, students' interest, etc. Though it has considerable limitations, a whole-class grouping has both practical advantages and disadvantages. Grouping students still have some disadvantage such as that as individual students do not have equal opportunity to express anything on their own, that it is not the effective way to organize communicative language teaching 
or specifically task-based sequences, etc. (Harmer, 2001).

Blair (In Abdullah, 2016) has stated that group work (including pair work) has at least five pedagogic benefits. Group work (1) increases the quantity of language practice opportunities, (2) improves the quality of the students talk in several ways. They can engage in what is called "exploratory" talk and practice a functionally wider speech repertoire. (3) Helps individualize instructions, potentially allowing students to work at their own pace, perhaps using different materials. (4) Could help improve the effective climate in the classroom, the intimacy of the small group settings being especially valuable to shy or linguistically insecure students. Finally, group work can help motivate students because of the advantages referred to from (1) through (4) and because of the pedagogic variety it brings to a lesson.

Mostly in Group Work activities, the students will be asked to sit together, face one another, and talk freely about various topics. This situation creates free communications in which the students use the language freely in the classroom without feeling shy. Group work activities are usually discussions in groups with up to four students in each group in order to give every students maximum opportunity to participate in all speaking activities (Abdullah, 2016).

There are some researches that showed the effectiveness of the method. La'biran (2017) stated that the small group discussion strategy can improve the speaking ability of the students and increase students' activity. Arifin, et.al. (2014) also found through research that the highest improvement of students' achievement by implementing group work method is the fluency. This occured because students always practice to speak and apply selfcorrection to control their speed and accuracy in speaking.

Based on the information above, the researcher here tried to make a classroom research, using group work activities. Here the researcher tried to minimize the weakness of the method by putting students into small group consisted of four or five persons, gave students' autonomy by allowing them to make their own decisions in the group (Hammer, 2001) and encouraged students to broaden their teamwork skills in their groups.

This research is undertaken to see whether the group work method in teaching speaking English has any positive effects on their speaking skill and their academic achievement of the students of Polytechnic ATI Makassar. It is expected that the finding of this research will give useful contribution to the process of teaching and learning speaking at Polytechnic ATI Makassar. This research then also serves as a platform of evaluation by researchers who intend to carry out similar study in the future.

\section{Review of the Related Literature}

When people think about the activities of teaching and learning, especially when it involves a group work, they probably imagine a picture of students sitting in rows listening to a teacher who stands in front of them. In fact, this is what teaching used to be, and it is still the most common form of teacher-student interaction in many cultures. Though it has many limitations, grouping students is one way to deliver the materials well to reach the target of teaching.

Harmer (2001) stated that one of the advantages of group work is promoting learners' autonomy by allowing students to make their own decision in the group without being told what to do by teacher. In general, it is possible to say that small groups of around five students provoke greater involvement and participation.

\section{Group Work Activity}

Lie (2002) defines that cooperative learning through group work is learning system that gives opportunity to students to cooperate with complete and structural tasks. Good (2003) defines that group 
activity increases the opportunities for all learners to speak the new language, it allows them to learn from each other, and frees the teacher to monitor individuals and give them feedback.

\section{Advantages of Group Work}

Holt; et al in Good (2003) describes the advantages of group work: the cooperative learning method used in a group work is a valuable strategy for teaching at diploma, especially useful for students from diverse linguistic and culture backgrounds who are learning English as a second language. It offers a method for managing diversity into a positive force for improving school performance, and involving students in classroom communication and activity.

Cooperative learning strategies can be used in a variety of ways and time period and builds language skills. Such collaborative activities include games for exchanging personal information, problem solving exercises, brainstorming, group discussion, cooperative review of information, and story sequencing.

\section{RESEARCH METHOD}

This research used a combination of descriptive qualitative and quantitative analyses. Quantitative data were tested by using correlation analysis. Then the result was analyzed by using qualitative analysis. This research was carried out through giving some materials, applied the method, and then giving direct testing such as written test to find out how far students understand about the materials after they discussed in a group. It was one of the assessment materials. Others assessments were taken from groups' activities in classroom, groups' presentation, Individual's interview test and questionnaire.

The population of this research was the students of Agro Industrial Engineering, Polytechnic ATIM class A, who studied for General English II at the second semester. The total numbers of them were 20 students, chosen randomly. They were taught for two months in 6 meetings and each meeting was delivered in 50 minutes. The data were collected from groups' activities in the classroom, group's presentation, individual's interview and written test. All the data were analyzed on computer by using Microsoft Excel. The result was used to identify whether the group method or treatment could improve students' academic achievement in learning and students' skills in speaking English effectively.

\section{FINDING AND DISCUSSION}

These lessons were divided into six meetings with six different materials to be discussed and performed, such as business introduction (social gathering in business meeting), getting directions, products and services, making presentation, on the phone, placing and ordering and job interview test. During the activity process, the lecturer observed, guided and also directed the students, motivated them to be more active and placed the most proficient students into each group to help the underperforming students. Teacher gave assessment through observation sheets. The assessment weight range from 88-100 (very good), 80-less than 88 (good), 75-less than 80 (fairly good) and 65-less than 75 (satisfactory). All materials were prepared and given to them before the class began to help them understand the materials easier and also to help them adapt with their roles and prepare themselves.

At the first and the second meetings, for the topic of business introduction and getting directions, students were placed as if they were at business gathering. They met with some important clients and they made acquaintances to many people. They were asked to make name cards and they used the cards as their identities. They would ask about their new colleagues' office location and try to identify the location. It was the first time for them to speak in group and have role play therefore I found that some students were not serious, 
a little bit passive, still shy and still difficult to play the role that they have chosen. It might be because they were still new with this simulation. They were still reading the text. They were also still confused and not expressive in playing their role. The proficient students still dominated but they also helped and motivated the underperforming students to speak and enjoy the activity. The lecturer tried to find the solution to problems above after interviewing them about their topics. They just need time and opportunity to be better.

The third and the fourth meetings were about products and services, and making presentation. Students were asked to read the material about how to have good presentation and brought some brochures of products. They were asked to become a senior marketing and would give presentation in front of some businessmen. These topics were interesting for them, perhaps because they had learnt about marketing. Therefore, students became more active, even though there were two or three students still stayed passive. Students also started to be serious, enjoyed their roles as senior marketing and as the audience in the company's presentation. Here, I found that some students could develop themselves well and improve their performance. They also learnt by doing, how to be good listener and speaker, respect to others opinion and not dominating the discussion.

The fifth and the sixth meetings were about on the phone, placing and ordering and job interview test. Students were asked to read the material about how to have good conversation on telephone and they were also asked to prepare some brochures of products of food and hotels services. They were asked to become waiters and waitresses in restaurants and also as hotel staff. They gave information about the food and the hotel information to their customers. These topics were interesting for them, perhaps because they also learnt about communication. Therefore students became more active and enjoyed the role playing in group. Students also started to be more serious, and tried to be professional by answering questions about their restaurants' and the hotels products and facilities. Some students could develop their self-confidence and improve their performance. They also learnt how to give good information to customer by practicing it.

After they discussed and had some presentation in groups, then students were asked to have interview test. The materials of the test came from all the materials given in class before. It was a way to find out whether students understand the material and could improve their skill in speaking or not.

Table 1 shows that there is a good improvement of the students' proficiency, such as in speaking and writing, after grouping them. It shows also that students have a good progress after giving them tests for three times such as individual interview and for once, group presentation and writing test. Most of them showed significant progress in individual tests, from test one to test three, but it can be seen from the table 1 also that those who achieved good result in individual interview, did not show the same in group's presentation. Some of them around nine students only got 60 to 65 in presentation however others got 70 to 85 . After seeing the difference result then the writer tried to find out the fact by interviewing the nine students who got 60 to 65 in presentation. Most of them answered that they have not enough bravery to talk in front of the group. They prefer to speak face to face in individual interview session.

Figure 1 shows the visualization of the students' progress after the treatment. The alternative teaching method, group work, that the research offered, has shown a significant change. The group work is successful in this research because this method allows students to look at the discussion material, work and discuss in their own group. This method gave them 
confidence in their ability to use language grammar by helping each other in group. and in their ability to understand English

Table 1. The Result of Individual Interview, Group's Presentation and Written Test

\begin{tabular}{|c|c|c|c|c|c|}
\hline $\begin{array}{l}\text { Student } \\
\text { Number }\end{array}$ & $\begin{array}{l}\text { Individual } \\
\text { Interview } 1\end{array}$ & $\begin{array}{r}\text { Individual } \\
\text { Interview } 2\end{array}$ & $\begin{array}{l}\text { Individual } \\
\text { Interview } 3\end{array}$ & $\begin{array}{c}\text { Groups' } \\
\text { Presentation }\end{array}$ & $\begin{array}{c}\text { Written } \\
\text { Test }\end{array}$ \\
\hline Student 1 & 70 & 75 & 75 & 70 & 70 \\
\hline Student 2 & 75 & 80 & 80 & 75 & 75 \\
\hline Student 3 & 65 & 70 & 70 & 65 & 70 \\
\hline Student 4 & 75 & 80 & 80 & 70 & 80 \\
\hline Student 5 & 70 & 75 & 75 & 70 & 75 \\
\hline Student 6 & 70 & 75 & 75 & 70 & 70 \\
\hline Student 7 & 75 & 80 & 80 & 75 & 75 \\
\hline Student 8 & 70 & 70 & 70 & 65 & 70 \\
\hline Student 9 & 65 & 75 & 75 & 65 & 70 \\
\hline Student 10 & 70 & 80 & 80 & 65 & 75 \\
\hline Student 11 & 65 & 75 & 75 & 65 & 70 \\
\hline Student 12 & 85 & 88 & 88 & 80 & 80 \\
\hline Student 13 & 70 & 70 & 70 & 60 & 70 \\
\hline Student 14 & 70 & 75 & 75 & 60 & 70 \\
\hline Student 15 & 70 & 80 & 80 & 70 & 70 \\
\hline Student 16 & 75 & 85 & 85 & 75 & 80 \\
\hline Student 17 & 65 & 70 & 70 & 65 & 65 \\
\hline Student 18 & 85 & 90 & 90 & 85 & 85 \\
\hline Student 19 & 75 & 80 & 80 & 75 & 80 \\
\hline Student 20 & 65 & 70 & 70 & 65 & 70 \\
\hline
\end{tabular}

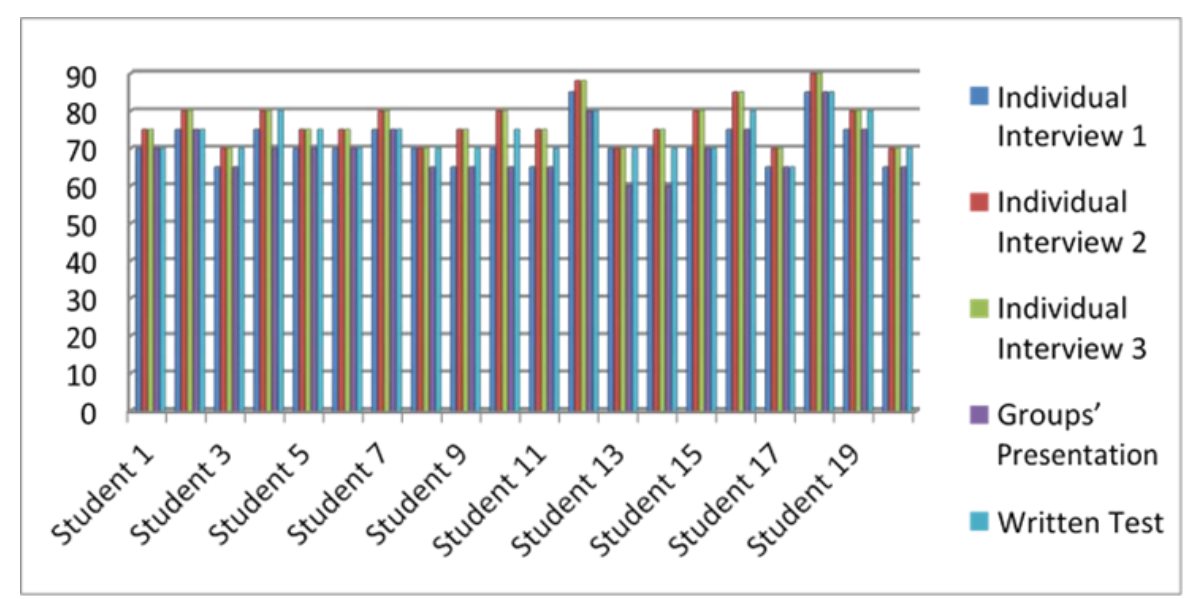

Figure 1. The Students' Progress after the Treatment 
The lecturer, in this approach, serves more as a guide than as a formal lecturer after giving explanation about the materials. The teacher watches and guides the students to the right direction. Thus, the students take a more active role in the learning process and more independent role as well. After doing this research, the writer believes that the group work is an effective method in teaching English Speaking because they could help each other to understand the material, support ideas and shared the experience.

After that students were asked to fill the questionnaires form which consisted of six statements. The answer was only Yes or No, it depended on how was their opinion about the method. The statements were related to the importance of group work in learning English, Group Work method can improve students' knowledge in grammar, group work method can motivate students in learning grammar, group work method is the effective method in teaching grammar, group work method can make students active in learningteaching process and Maximize Teacher Talking Time (TTT) and Minimize Students Talking Time (STT).

\section{Analysis of Questionnaires}

Table 2 indicates that $100 \%$ or all of the students think that group work is important in studying English. Where they can support, help and motivate each other in group.

Table 2. The importance of group work in learning English

\begin{tabular}{|c|c|}
\hline Stage & Class of TIA C \\
\hline Number of students & 20 \\
\hline Yes response & 20 \\
\hline$\%$ & 100 \\
\hline No response & 0 \\
\hline$\%$ & 0 \\
\hline
\end{tabular}

Table 3 indicates that 15 students or $75 \%$ of the students think that group work method can improve their knowledge in grammar because when they discussed and one of them made mistake in grammar, other students will correct it. Only $25 \%$ or 5 students think that this method cannot improve their knowledge in grammar.

Table 3. Group Work Method Can Improve Students' Knowledge in Grammar

\begin{tabular}{|c|c|}
\hline Stage & Class of TIA C \\
\hline Number of students & 20 \\
\hline Yes response & 17 \\
\hline$\%$ & 75 \\
\hline No response & 5 \\
\hline$\%$ & 25 \\
\hline
\end{tabular}

Table 4 indicates that 15 students or $75 \%$ of the students think that group work method can motivate them in learning grammar. It happened because if one of them thought it was difficult to speak because of the lack of vocabularies, others will motivate him by helping him to make his own sentences with their ideas. Only $25 \%$ or 5 students at this class think that this method cannot motivate them in learning grammar.

Table 4. Group Work Method Can Motivate Students in Learning Grammar

\begin{tabular}{|c|c|}
\hline Stage & Class of TIA C \\
\hline Number of students & 20 \\
\hline Yes response & 15 \\
\hline$\%$ & 75 \\
\hline No response & 5 \\
\hline$\%$ & 25 \\
\hline
\end{tabular}

Table 5 indicates that $75 \%$ or 15 students in the class think that group work method is the effective method in teaching grammar. There are only $25 \%$ or 5 students at this class think that the teaching method is not the effective method in teaching grammar. 
Table 5.Group Work Method is The Effective Method In Teaching Grammar

\begin{tabular}{|c|c|}
\hline Stage & Class of TIA C \\
\hline Number of students & 20 \\
\hline Yes response & 15 \\
\hline$\%$ & 75 \\
\hline No response & 5 \\
\hline$\%$ & 25 \\
\hline
\end{tabular}

Table 6. Group work method can make students active in learning - teaching process

\begin{tabular}{|c|c|}
\hline Stage & Class of TIA C \\
\hline Number of students & 20 \\
\hline Yes response & 16 \\
\hline$\%$ & 80 \\
\hline No response & 4 \\
\hline$\%$ & 20 \\
\hline
\end{tabular}

Table 6 indicates that $80 \%$ or 16 students think that group work method can make students active in learning - teaching process. Only $20 \%$ of the students think that this method cannot make students active in learning-teaching process.

Table 7. Maximize Teacher Talking Time (TTT) and Minimize Students Talking Time (STT)

\begin{tabular}{|c|c|}
\hline Stage & Class of TIA C \\
\hline Number of students & 20 \\
\hline Yes response & 6 \\
\hline$\%$ & 30 \\
\hline No response & 14 \\
\hline$\%$ & 70 \\
\hline
\end{tabular}

Table 7 indicates that there are $70 \%$ or 14 students disagreeing with the statement. They think that teachers have to minimize talking time in teaching in order to give the students much time to implement their English.

These questionnaires prove that this method is preferred by the students because they can be more active in using the target of language. This method also can work best because it will force the students to think critically and use their knowledge of the language to come up with the rules.

The researcher found from the questionnaires that $100 \%$ of the students think that working in group is important in studying speaking English, $75 \%$ of the students think that this method can improve their knowledge by sharing experience in group, $75 \%$ of the students think that this method can motivate them in learning English, 75\% think that this teaching method is the effective method in teaching speaking, $80 \%$ think that this teaching method can make students active in learning- teaching process. Students also said that teachers have to minimize talking time in teaching in order to give the students much time to implement their English. These questionnaires prove that this teaching method is preferred by the students because they can be more active in using the target of language.

The method has played a positive role in providing practice to the students in the use of language and in improving the academic achievement. This research found the effectiveness of teaching speaking using the method of group work.

\section{CONCLUSION}

This research has been done simply to find the data in order to decide if this method is effective or not in teaching speaking. The findings of the study led to the conclusions that the problem of teaching speaking could be solved by adopting and practicing the group work method. The teaching of speaking through group work played positive role in improving the academic achievement of the students studying English. This can be seen from the result of the tests which increased significantly. It happened because students are more actively involved in the learning process.

Based on the result of the study, it 
was found that there was an improvement in students' speaking achievement from test-1, test-2, and test-3. The interview sheets and the observation sheet also showed the improvement that the students were more interested and motivated in speaking English. It means that there was an improvement on students' speaking achievement through group works not only the score, but also motivating the students to dare to speak English. Overall, they also got additional knowledge such as how to be a good listener and speaker, how students could develop their selfconfidence and improve their performance. They learnt by doing. This fact is suitable with the wise words which are made by Chinese famous philosophy, Confucius (in Zaini, et. all, 2002:13), he stated that: "What I hear, I forget. What I see, I remember. What I do, I understand".

The lecturer, in this approach, serves more as a guide than as a formal lecturer. The teacher watches and guides the students in the right direction. Thus, the students take a more active in group in the learning process and more independent role as well. After doing this research, the research believes that group work is one of effective method in teaching Speaking English. It will work best because it will force the students to think critically and use their knowledge of the language. Students became more independent to use this method because they take a part of every activity, they think, they act they feel it and they help each other.

\section{REFERENCES}

Abdullah. (2016). Group work Activities for Improving Skills. English Education Journal. Sigli, Aceh.

Arifin, Desi Zauhana, dkk. (2014). Increasing Students' Speaking Ability Through Group work. Jurnal FKIP UNILA. Volume 3 Nomor 2.

Burney, Aqil. (2008). Inductive and Deductive Approach. Department of
Computer Science University of Karachi.

Good, Carter V (Ed.). (1973). Dictionary of Education. New York: McGraw Hill Book Company.

H. Widodo. (2004). Approaches and Procedures for Teaching Grammar English Teaching: Practice and Critique. Retrieved from: http://www.teachingenglish.org.uk /think /articles/presenting-newlanguage on 22 April 2009.

Harmer, Jeremy. (2001). The Practice of English Language Teaching. London: Longman.

Harris, Brown. (2003). What are some Different Teaching Methods. Retrieved June 11, 2009, from http://www.wisegeek.com/teachment h.htm.

Heinle \& Heinle Publishers. http://www.teachingenglish.org.uk/th ink/articles/presenting-new-language

Heinle \& Heinle Publishers. Retrieved from

http://www.sdkrashen.com/SL_Acquis ition_and_Learning

La'biran, Roni. (2017). Improving Speaking Ability through Small Group Discussion for the Eight Year Students of SMPN Saluputti in Tana Toraja. ELITE, Vol. 04, Nomor 01, Juni 2017. UKIP Toraja.

Lie, Anita. (2008) .Pengajaran Bahasa Asing Antara Sekolah dan Kursus. Associate Director ASIA TEFL (Teachers of English as a Foreign Language). Retrieved from http://www.google.co.id/search?q=un dangundang+pendidikan+ttg+bhs+inggris $\&$ hl $=$ id \&start $=10 \& s a=\mathrm{N}$

Zaenab, Zainal. (1989). Teaching English through Grammar Translation Method and Communicative Method: A Comparative Study. Unpublished Paper. Faculty of Letters, Hasanuddin University, Makassar. 